\title{
Expression of Stromelysin-3 in the Human Placenta and Placental Bed
}

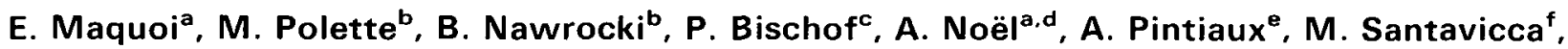 \\ J.-P. Schaaps ${ }^{\text {e }}$, R. Pijnenborg ${ }^{f}$, P. Birembaut ${ }^{b}$ and J.-M. Foidart ${ }^{a, g}$ \\ a Laboratory of Biology, University of Liège, Sart Tilman, Belgium \\ b INSERM U-314, CHU Maison Blanche, Reims, France \\ c Department of Obstetrics and Gynecology, University of Geneva, Geneva, Switzerland \\ d Department of Obstetrics and Gynecology, University of Liège, CHR Citadelle, Liège, Belgium \\ "INSERM U-184, CNRS IGBMC, Faculté de Médecine, Illkirch, France \\ 'Department of Obstetrics and Gynecology, U.Z. Gasthuisberg, Leuven, Belgium \\ Paper accepted 17 December 1996
}

Human placentation is mediated by fetal trophoblastic cells which penetrate into the decidualized uterine endometrium. Trophoblast invasion requires the precisely regulated secretion of specific proteinases able to degrade the endometrial basement membranes and extracellular matrix. To document further the involvement of these proteinases during human placentation, we evaluated in vivo the expression of stromelysin-3, a member of the metalloproteinase family, during the first and third trimesters of pregnancy, by means of immunohistochemistry, in situ hybridization and Northern blot analysis. Human extravillous trophoblasts invading the maternal decidua produced stromelysin-3 during both, the first and third trimesters of pregnancy, but to a lesser extent during the latter. In floating villi, stromelysin-3 expression was restricted to the syncytiotrophoblasts that line intervillous vascular spaces. In conclusion, stromelysin-3 is expressed by differentiated, non-proliferative villous and extravillous trophoblastic cells in early and late placental beds and villi, and its pattern of expression evolves during pregnancy. Our observations suggest that stromelysin-3 could play a role in human placentation. Placenta (1997), 18, 277-285

\section{INTRODUCTION}

Implantation of the human blastocyst and the subsequent placental development are dependent on trophoblast invasion of the decidualized endometrium. As implantation proceeds, undifferentiated villous cytotrophoblast stem cells (CTB) originating from the outer cell layer of the blastocyst divide and differentiate into morphologically and functionally distinct cell populations. In the villi, they fuse to form hormonally active villous syncytiotrophoblast (STB) which controls the transfer of solutes between maternal and fetal blood. Where villi contact the uterine wall, multilayered trophoblast cell columns (TCC) physically anchor the embryo to the decidua. In these columns, CTB differentiate progressively into nonproliferative, invasive and migratory intermediate trophoblasts (IT) (Damsky et al., 1992; Kliman and Feinberg, 1992; Damsky, Sutherland and Fisher, 1993). During the first 4 months of gestation [Figure 1(a)], these IT sprout from the TCC and migrate through the decidua and the inner third of the myometrium. They infiltrate the walls of the spiral arteries and replace the endothelial lining as far as the myometrial segment of the vessels. This invasive trophoblastic activity

* To whom correspondence should be addressed.

$01+3-400+/ 97 /(0+0277+09 \$ 12.00 / 0$ is characterized by the breaching of multiple basement membranes (including those of the endometrial glands, blood vessels and decidual cells) and the degradation of the interstitial extracellular matrix (ECM) of the decidua (Boyd and Hamilton, 1967; Brosens, Robertson and Dixon, 1967; Pijnenborg et al., 1980; Tuttel et al., 1985; Aplin, 1991; Foidart et al., 1992).

The human placenta thus functions as an invasive tissue, analogous to a locally invasive tumour (Liotta, 1986). However, unlike tumour invasion, trophoblast penetration is regulated precisely, both spatially and temporally, during gestation.

Several in vitro and in vivo studies have revealed that trophoblast cells have a regulated capacity to produce different matrix-degrading enzymes (Lala and Graham, 1990; Bischof and Martelli, 1992; Graham and Lala, 1992). Production of serine proteinases, such as urokinase-type plasminogen activator (u-PA) by trophoblastic cells correlates temporally with blastocyst invasion (Sherman, Strickland and Reich, 1976; Strickland, Reich and Sherman, 1976; Sappino et al., 1989; Behrendtsen, Alexander and Werb, 1992). The presence of u-PA, plasminogen activator inhibitor type 1 and u-PA receptor has been associated with infiltrating trophoblasts

(i) 1997 W. B. Saunders Company Ltd 


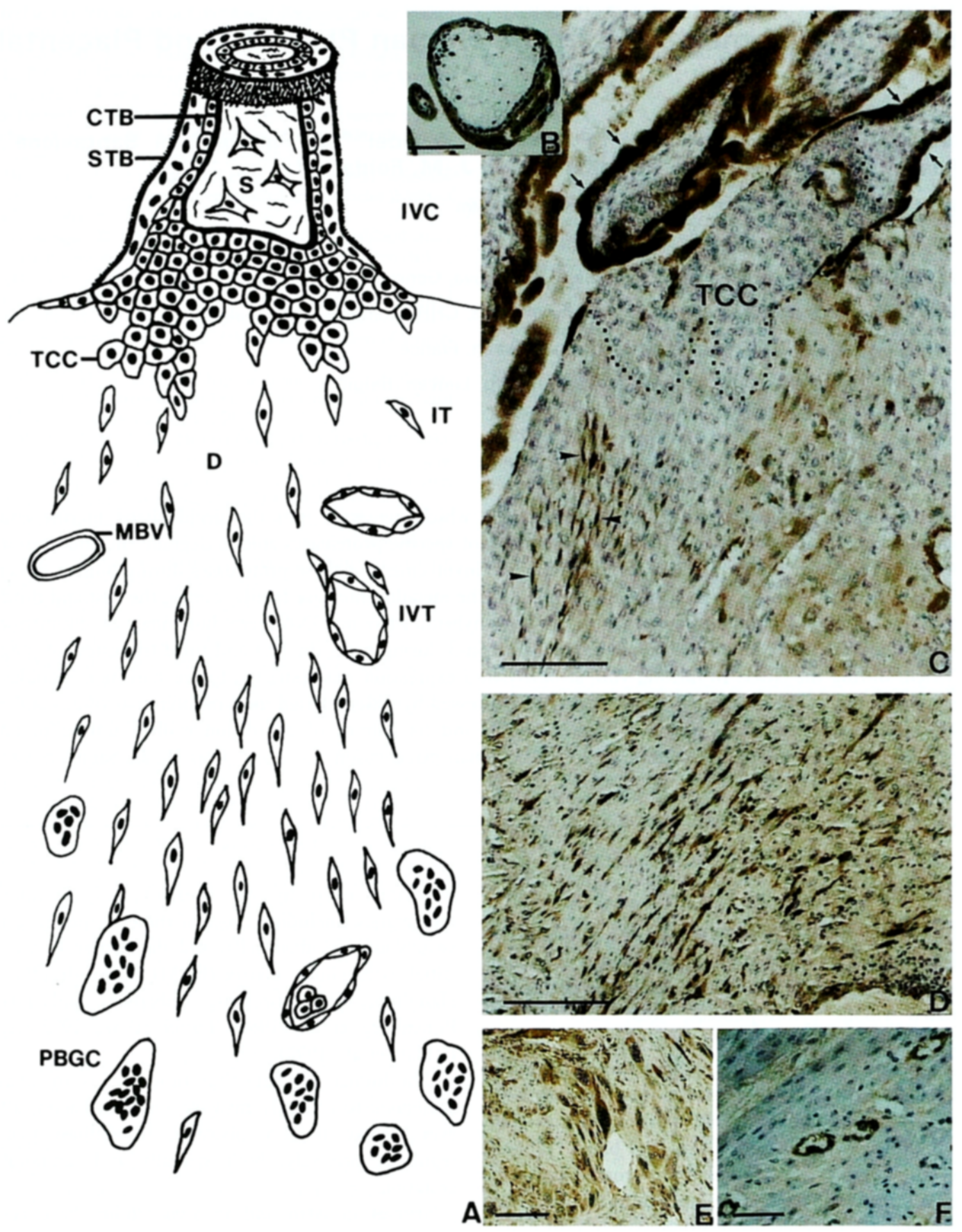

Figure 1. Localization of ST3 in a first trimester (11 weeks) placental bed. (A) Diagram showing the spatial organization of the fetal-maternal interface at the end of the first trimester. D, decidua; CTB, cytotrophoblast; IT, intermediate trophoblast; IVC, intervillous chamber; IVT, intravascular trophoblast; MBV maternal blood vessel; PBGC, placental-bed giant ceil; S, stroma; STB, syncytiotrophoblast bordered by sinusoids; TCC, trophoblastic cell column. (B) Transwerse section through a villus showing STB strongly labelled by the anti-ST 3 antibody. Scale bar $=100) \mu \mathrm{m}$. (C) Longitudinal section through the placental bed. Strong STB positivity (arrows) for ST3 is observed. ST3 is also expressed by some spindle-shaped IT (arrowheads) that are derived from negative TCC; become detached and infiltrate the maternal decidua. Scale bar $=150 \mu \mathrm{m}$. (D) Deeper in the decidua, numerous elongated IT, interspersed among negative decidual cells, were recognized by the anti-ST3 antibody. Scale bar $=200 \mu \mathrm{m}$. (E) Some IT fused to form PBGC which also express ST3. Scale bar $=150 \mu \mathrm{m}$. (F) The endothelial lining of the maternal blood ressels has been replaced by ST3-positive trophoblasts. Scale bar $=80 \mu \mathrm{m}$. 
(Feinberg et al., 1989; Zini et al., 1992; Hoffman et al., 1994). Members of the matrix metalloproteinases (MMP) family also appear to play a pivotal role during placentation. The acquisition of an invasive phenotype by early trophoblasts has been correlated with the ability of these cells to synthesize a large array of MMP: interstitial collagenase (Yagel et al., 1988; Moll and Lane, 1990), gelatinase A (Bischof et al., 1991; AutioHarmeinen et al., 1992; Fernandez et al., 1992; Blankenship and King, 1994; Polette et al., 1994), gelatinase B (Fisher et al., 1985; Emonard et al., 1990; Bischof et al., 1991; Librach et al., 1991; Behrendtsen, Alexander and Werb, 1992; Emonard et al., 1993; Polette et al., 1994), stromelysin-1 and stromelysin-2 (Brenner et al., 1989), as well as a membranetype MMP potentially involved in gelatinase $A$ activation (Nawrocki et al., 1996). The invasive trophoblasts and the maternal decidual cells also secrete specific inhibitors of these proteinases: plasminogen-activator inhibitors 1 and 2 (Feinberg et al., 1989; Hofmann et al., 1994), and tissue inhibitors of metalloproteinases 1 and 2 (Lala, and Graham, 1990; Polette et al., 1994). Thus, trophoblast invasiveness appears to be regulated tightly by the balance between the activated enzymes and their inhibitors.

A few years ago, another member of the MMP family, stromelysin-3 (ST3), was identified (Basset, Wolf and Chambon, 1990). ST3 exhibits the same general features as previously described MMP, including a typical zinc-binding site and a conserved cysteine residue characteristic of the MMP prodomain (Basset, Wolf and Chambon, 1993). Although its physiological substrate is still unknown, ST3 is probably a proteinase, because the purified protein exhibits proteolytic activities (Murphy et al., 1993). However, ST3 displays functional properties and an activation mechanism different from that of other MMP (Birkedal-Hansen et al, 1993; Murphy et al., 1993; Pei, Majmudar and Weiss, 1994; Noël et al., 1995; Santavicca et al., 1996). Wolf and co-workers demonstrated that st 3 transcription in embryonic fibroblasts can be induced by 12-o-tetradecanoyl phorbol 13-acetate and growth factors, thereby suggesting a transcriptional regulation similar to that of interstitial collagenase, stromelysin-1 and gelatinase B (Wolf et al., 1992). According to those data, ST3 appears to belong to a new MMP subfamily that exhibits its proper enzymatic characteristics and narrow substrate specificity (Basset et al., 1993; Murphy et al., 1993; Pei, Majmudar and Weiss, 1994; Noël et al., 1995). The st 3 gene is known to be expressed in the stromal compartment of most invasive human carcinomas and the highest levels of ST3 transcripts are found in tumours demonstrating high local invasiveness (Urbanski et al., 1992; Wolf et al., 1992; Basset, Wolf and Chambon, 1993; Birkedal-Hansen et al., 1993; Hähnel et al., 1993; Kawami et al., 1993; Muller et al., 1993; Polette et al., 1993; Segain et al., 1993). However, ST3 transcripts are also present in healthy situations in which extensive ECM remodelling occurs: embryonic development (Basset et al., 1990), frog metamorphosis (Patterson, Pär Hayes and Shi, 1995), mammary gland involution (Lefebvre et al., 1992), normal uterus and, interestingly, at very high levels in human term placenta (Basset et al., 1990).

To localize ST3 in placental tissues and to investigate the potential role of this enzyme during human placentation, immunohistochemical labelling, in situ hybridization and Northern blot analysis were used to evaluate the expression of ST3 in first and third trimester placental tissues from normal pregnancies.

\section{MATERIALS AND METHODS}

\section{Tissue preparation}

Samples of human placental villi obtained from 16 first trimester therapeutic abortions and 10 term third trimester placentae immediately after delivery were examined. Twelve placental-bed biopsies were obtained in situ with echoguided sampling forceps during the first and third trimesters of normal pregnancies. This procedure allows precise anatomical localization (placental bed) of the sample and prevents the tissue disruption observed during abortion or delivery (Hustin and Franchimont, 1992). Finally, four full-thickness implantation sites in hysterectomy specimens taken at 8.5-13 weeks of pregnancy were also studied. One part of each sample was frozen in liquid nitrogen for Northern blot analysis, while the remainder was fixed in formalin and embedded in paraffin for in situ hybridization and immunohistochemical studies.

\section{Immunohistochemistry}

Immunolabelling of ST3 was accomplished according to the following procedure. Endogenous peroxidase activity was quenched by a 10 -min incubation with 3 per cent hydrogen peroxide in phosphate-buffered saline (PBS). Tissues sections were subjected to three 5 -min heating cycles in citric acid buffer ( $\mathrm{pH} \mathrm{6)}$ in a microwave oven (Philips, power setting: $750 \mathrm{~W})$. Non-specific antibody binding was blocked by incubation in 7 per cent bovine serum albumin-PBS (BSAPBS) for $30 \mathrm{~min}$. Sections were incubated overnight at room temperature with a mouse monoclonal antibody raised against the haemopexin domain of ST3 (5ST-4A9) (Wolf et al., 1993; Santavicca et al., 1995), grown as an ascites fluid and used diluted 1/4000 in 3 per cent BSA-PBS. A biotinylated secondary antibody (LSAB $2 \mathrm{Kit}$, Dako, Denmark) was applied for $30 \mathrm{~min}$ prior to incubation with streptavidin-horseradish peroxidase (LSAB $2 \mathrm{Kit}$ ) for an additional $30 \mathrm{~min}$. Antibody localization was visualized with a solution of diaminobenzidine and 0.03 per cent hydrogen peroxide. Each step of the procedure was followed by three washes in PBS.

To evaluate the specificity of immunolabelling, the primary antibody was replaced by either an ascites fluid containing 5ST-4A9 which was preincubated with immobilized recombinant ST3 (Santavicca et al., 1995) or an isotype-matched 

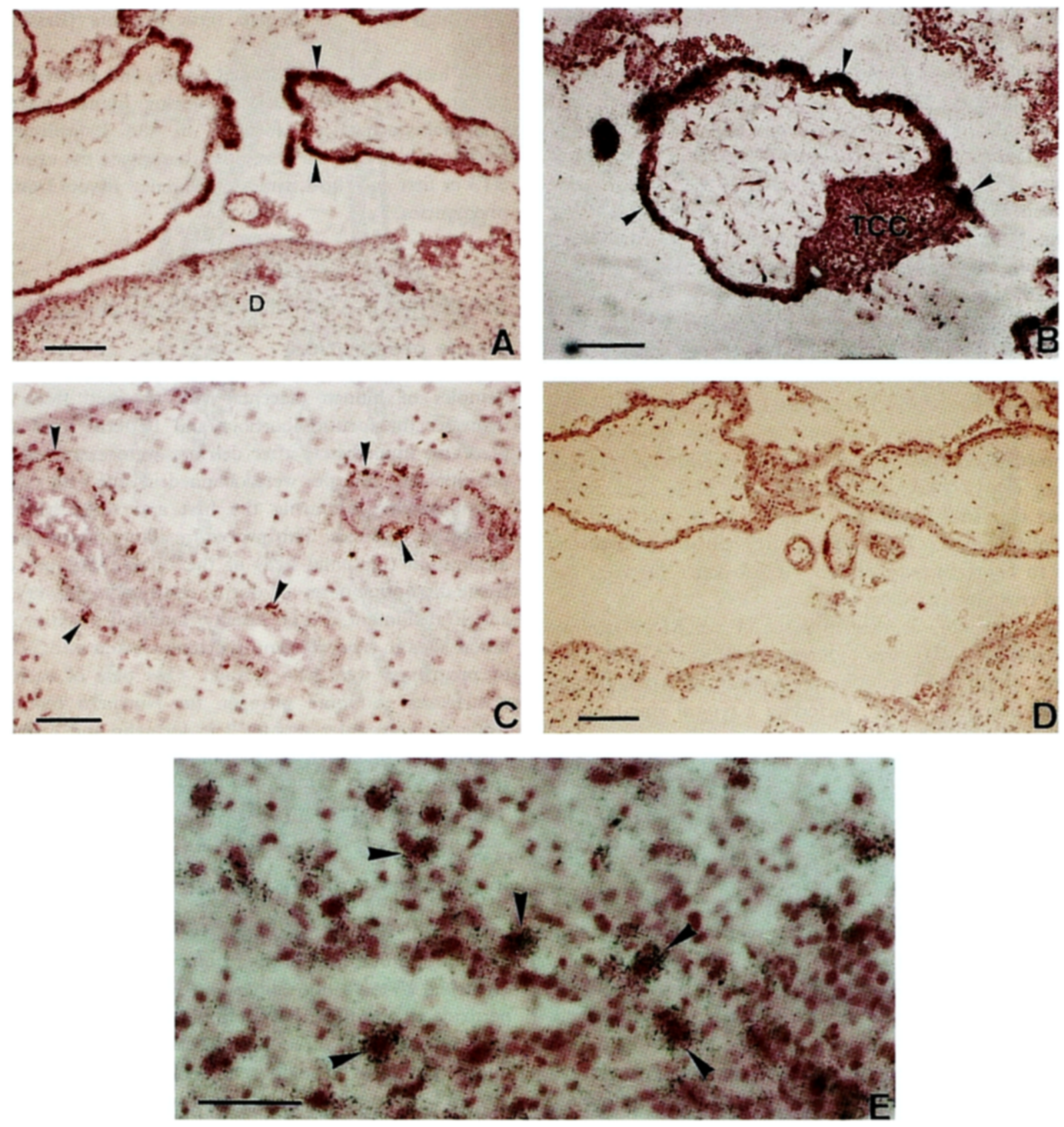

Figure 2. Lecalization of $S T 3$ mR.NA in first trimester villi and placental beds. (A) mRNAt transcripts of ST3 are detected in the $S T B$ (arrowheads) of villi. The

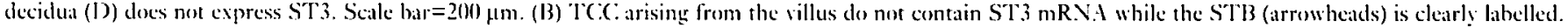

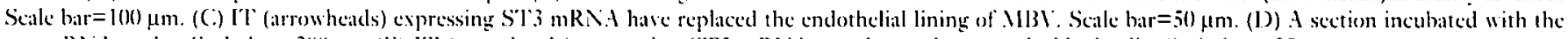
sense R.A probe. Scale har $=2(0) \mu \mathrm{m}$. (L) I'T (armwheals) expressing $S T 3$ mRNA are observed among decidual cells. Scale bar $=25 \mu \mathrm{m}$.

irrelevant antibody (a mouse ascites fluid raised against hamster CD-3). No immunoreactivity was observed in the controls.

Epithelial cells and trophoblasts were identified by immunohistochemical labelling with a monoclonal antibody to crtokeratins 8/18 (CA.M 5.2, Becton-Dickinson) revealed with a rabbit anti-mouse antibody conjugated to horseradish peroxidase $(1 / 50$ in PBS; Dako). All sections were counterstained with hematoxylin, mounted, and examined under an Olympus AH3 microscope.

\section{In situ hybridization}

Paraffin was removed from $5-\mu \mathrm{m}$ thick tissue sections which were then rehydrated and treated with $0.2 . \mathrm{M} \mathrm{HCl}$ for $20 \mathrm{~min}$ at room temperature, followed by a $15-\mathrm{min}$ incubation at $37^{\circ} \mathrm{C}$ with proteinase $\mathrm{K}(1 \mu \mathrm{g} / \mathrm{ml}$ in Tris-ethylenediaminetetraicetic acid-NaCl; Sigma Chemical Co., St Louis, MO, USA) to remove basic proteins. The sections were washed in $2 \times \mathrm{SSC}$ (saline-sodium citratc), acetylated in 0.25 per cent acetic anhydride in 0.1 .11 triethanolamine for $10 \mathrm{~min}$ and hybridized 

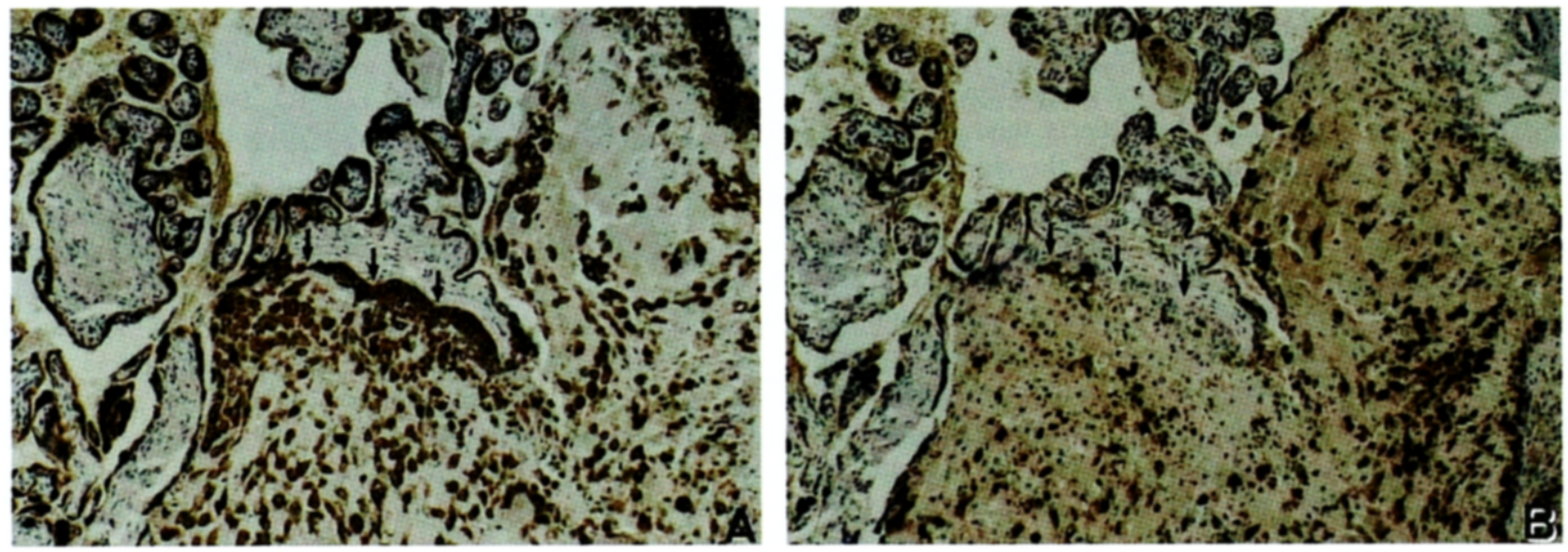

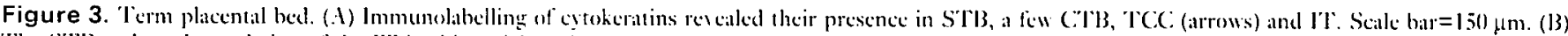

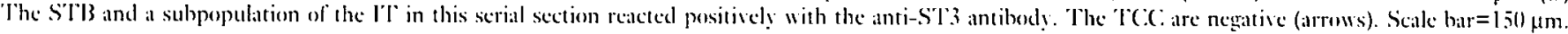

orernight with ${ }^{35}$ S-labelled antisense RNAt transcripts. ST3 cDNA insert (1600-bp \% IV probe; Basset et al., 199.3) was subcloned into the Bluescript plasmid (Stratagene, I a Jolla, C.A, LSA) and used to prepare "is-labelled RNA probes. Hybridizations were followed by RNase treatment (20) $\mu \mathrm{g} / \mathrm{ml}$, $1 \mathrm{~h}, 37^{\circ} \mathrm{C}$ ) to remove unhybridized probes. Four stringent washes ( $2 \times \mathrm{SSC}$ and $1 \times \mathrm{SSC}, 15 \mathrm{~min}$ at room temperatture) were performed and autoradiography was carried out by using D19 emulsion (Kodak, Viliorde, Belgium). Slides were exposed for 21 days prior to development. The controls were performed under the sime conditions using ${ }^{\text {i5 }} \mathrm{S}$-labelled sense RNA probes. All slides were counterstained with haematoxylin, mounted and examined under an Olympus $\mathrm{AH} 3$ microscope. Control slides were negative.

\section{Northern blot analysis}

Total RNA was extracted from tissues by RNAzol treatment (Biogenesis, Bournemouth, UK). An aliquot of RN.t (15 $\mu \mathrm{g})$ was electrophoresed on 1 per cent agarose gels, containing 10 per cent formaldehyde and transferred onto a nylon membrane (Hỵbond $d^{(\text {'til) }}-\mathrm{N}$; Amersh:am, Gent, Belgium). The membrane was hybridized with a cDN.4 probe (als described above), that had been labelled with ${ }^{32} \mathrm{P}$ using random priming synthesis (Bochringer Mannheim, Mannheim, Germany). The filter was exposed for 1 day for floating villi and 7 days for placental beds (six independent samples were analysed for each gestational stage). The membrane was rehybridized to an oligonucleotide probe of human $28 \mathrm{~S}$ rRNA (Cloneth, Palo Alto, CA, USA), which served as a control. The amounts of ST3 transcripts were quantified by densitometric analysis of autoridiographs of the Northern blots. All results were corrected for RNA loading by densitometric data obtained for the $28 \mathrm{~S}$ rRNA signals.

\section{RESULTS}

Immunolabelling of the first trimester placental-bed biopsies and implantation-site sections with anti-cytokeratin antibody revealed mainly two different trophoblastic populations: the anchoring TCC (composed of rounded uniform cohesive cells) that sprouted from the base of the villi and penetrated into the deciduat; and fusiform I'T that rose from the tips of the TCC and infiltrated the placental bed as deep as the myometrium. Some of these I'T were locited in the maternal arterial walls and lumen as intrarascular trophoblasts (IVT), while others fused with each other to form multinucleated placental-bed giant cells (PBGC) (Loke, 1990). When sections were incubated with anti-ST3 antibody, the villous CTB and their developing TCC anchors were unreactive. In contrast, clearly positive IT and PBGC were interspersed among negative decidual cells throughout the placental-bed thickness [Figure 1(C), (D) and (E)|. In some maternal blood ressels, the endothelial lining had been replaced by ST3-positive trophoblasts [Figure 1(F)|. Decper in the myometrium, sery few ST3-positive trophoblastic cells were observed (data not shown).

In situ hybridization data clearly indicated that $S T 3$ mRNA was localized in the same immunoreactive cell populations (i.e. IT, PBGC and IVT) in the first trimester placental beds (Figure 2).

Analysis of first trimester floating villi by both immunohistochemistry and in situ hybridization revealed that the STB layer, which borders the villous surface, was strongly positive for ST3 protein and mRNA transcripts. In contrast, no detectable label was observed in the underlying villous CTB or in the stromal core (including the fetal fibroblasts, Hofbauer's cells and vascular endothelial cells) [(Figures $1(B)$ and 2(A)].

As gestation progresses, placental morphology changes. In floating villi, the villous surface expands and the CTB become widely separated. When term floating villi were examined, only STB were positive for ST3; CIB and the stromal core were negative [Figure 3(B)]. These findings were confirmed by hybridization studies (data not shown). In term placental beds, the TCC had frequently lost their structure and were limited to a few cell layers. Their precise delimitation required cytokeratin immunolabelling [Figure 3(A)]. As illustrated 
in Figure 3(B), the TCC were negative for ST3. In the decidua, cytokeratin-positive IT were present [Figure 3(A)] but they had assumed a more rounded shape than during the first trimester, an observation that reflects their diminished migratory capacity. Immunolabelling of the third trimester placental beds did not reveal any significant modification in the expression pattern of ST3. No immunoreactivity was observed in TCC, while positivity was only seen in IT [Figure 3(B)]. ST3 mRNA localization was restricted to IT (data not shown).

These histological studies were complemented by Northern blot analysis in order to obtain a semiquantitative evaluation of ST3 mRNA expression [Figure 4(A)]. Densitometric scanning of the blots, after standardization for the total amount of mRNA deposited on the gel, indicated that in floating villi, the level of ST3 mRNA increased threefold from the first trimester to term [Figure 4(B)]. In contrast, the level of ST3 mRNA measured in placental beds was 4.5 -fold lower at term than during the first trimester [Figure 4(B)].

\section{DISCUSSION}

In this study, the in vivo expression of ST3, a member of the MMP family, was analysed in human placenta during the first and third trimesters of gestation. To the best of our knowledge, this is the first demonstration of the spatiotemporal distribution of this enzyme during human pregnancy.

The processes of implantation and placentation both depend on the penetration and remodelling of the uterine endometrium and vasculature by invasive trophoblasts. The migratory nature of human trophoblasts resembles closely that of highly invasive tumours, so that the normal trophoblasts have been called 'pseudomalignant' (Strickland and Richards, 1992). In the pregnant endometrium, the decidual cells surround themselves with a sparse fibrillar network of different matrix proteins, including laminin, fibronectin, collagens I, III, IV, V, entactin, heparan sulfate proteoglycan, etc. (Wewer et al., 1985; Foidart et al., 1990; Damsky et al., 1992). To degrade these matrix components, human first trimester invasive trophoblasts have been shown to secrete a large array of proteolytic enzymes including u-PA (Hofmann et al., 1994), interstitial collagenase (Moll and Lane, 1990), gelatinase A (Fernandez et al., 1992; Polette et al., 1994), gelatinase B (Polette et al., 1994), and membrane-type MMP (Nawrocki et al., 1996).

Immunohistochemical labelling and in situ hybridization showed that, in addition to these previously described proteinases, extravillous invasive trophoblasts also express ST3 during the first and third trimesters of pregnancy. The level of ST3 expression was lower during the third trimester as revealed by Northern blot analysis. However, we can not completely exclude that this decreased ST 3 mRNA level could result from a reduced number of IT present in term placental bed biopsies.

Interestingly, CTB which proliferate to form TCC are initially noninvasive villous cells that progressively differentiate
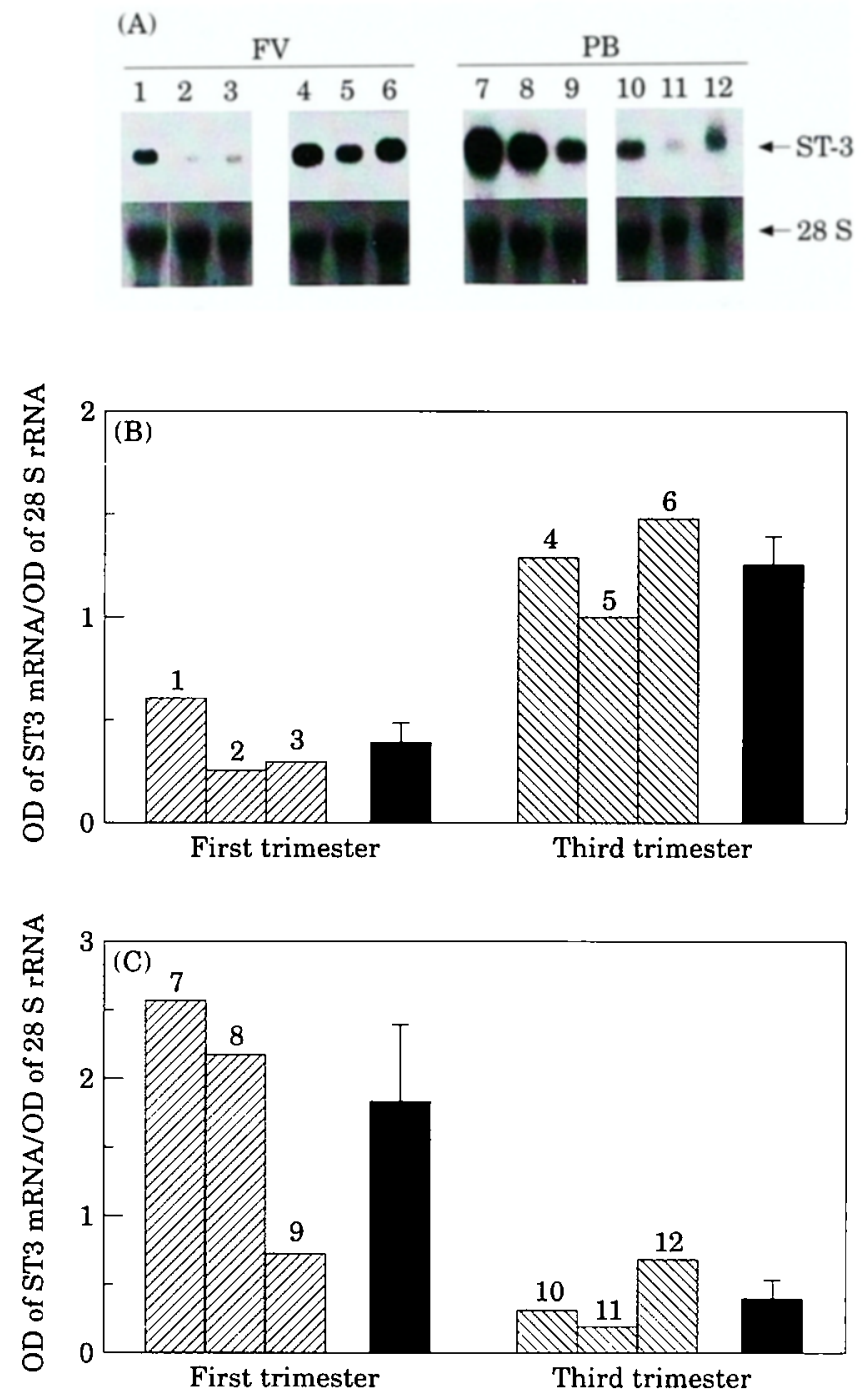

Figure 4. (A) Northern blot analysis of ST3 mRNA and $28 \mathrm{~S}$ rRNA in first and third trimester floating villi (FV) and placental beds (PB). Total RNA was isolated, elcctrophoresed and blot hybridized as described in 'Materials and Methods'. Lanes 1, 2, 3: first trimester FV $(9,8$, and 10 weeks, respectively); lanes $4,5,6$ : third trimester FV $(38,40$, and t0 weeks, respectively); lanes 7 , 8, 9: first trimester $\mathrm{PB}(9,8$, and 10 weeks, respectively); lanes $10,11,12$ : third-trimester PB (38, 40, and 40 weeks, respectively). (B) and (C) Densitometric analysis of the Northern blot. Lesels of ST3 transcripts in (B) floating rilli and $(C)$ placental beds of first and third trimesters were quantified by densitometric analysis of autoradiographs of the Northern blots. All results were corrected for RNA loading by densitometric data obtained for the $28 \mathrm{~S}$ rRNA signals. Results are expressed as optical density (OD) of ST3 signal/OD of $28 \mathrm{~S}$ rRNA. Relative OD of individual samples (hatched bars) and mean values for first and third trimesters (black bars) are presented. Gestation ages are identical to those described in (A).

into highly invasive IT (Damsky et al., 1992; Damsky, Sutherland and Fisher, 1993; Denker, 1993). They express ST3 only in their most distal regions, where they become embedded into the decidual compartment as IT. This spatially regulated onset of ST3 expression coincides with the downregulation of the $\alpha_{6} \beta_{4}$ integrin and the concomitant appearance of the $\alpha_{1} \beta_{1}$ integrin, which mediates the interaction of trophoblasts with different ECM ligands (Damsky et al., 1992; Damsky, Sutherland and Fisher, 1993). This switch in 
adhesion-molecule expression has been shown to contribute to the acquisition of an invasive phenotype by cultured CTB (Damsky et al., 1992; Damsky, Sutherland and Fisher, 1993; Denker, 1993). Moreover, integrin-ligand interactions have been reported previously to modulate the expression of MMP in several cell lines (Werb et al., 1989; Seftor et al., 1993; Seltzer et al., 1994). Therefore, we hypothesize that during the differentiation of CTB into invasive IT, ST3 expression could be induced by specific integrin-mediated interactions with ECM components. Our observations indicate that the expression of ST3 by these cells may contribute to the extensive basement membrane and stroma remodeling associated with first trimester trophoblast invasion.

In addition to the extravillous trophoblasts, we also localized ST3 in the villous STB which line the intervillous vascular spaces. Previous studies demonstrated the presence of u-PA, interstitial collagenase, gelatinase $A$ and $B$ and their corresponding inhibitors (plasminogen-activator inhibitors 1 and 2 and tissue inhibitor of metalloproteinase 1) in the villous STB (Feinberg et al., 1989; Moll and Lane, 1990; Fernandez et al., 1992; Hofmann et al., 1994; Polette et al., 1994). In this particular location, it is possible that ST3, in conjunction with the other proteinases, may play a role by preventing extensive perivillous deposition of fibrin. Such deposits would reduce the solute transfer between the maternal and fetal blood, thus dangerously limiting the exchange of nutrients and gases to the embryo.

It is interesting to note that the ST3 distribution pattern is very similar to that previously reported for u-PA (Hofmann et al., 1994). These two proteinases are expressed mostly in the same trophoblastic cells (STB, IT and IVT), suggesting that both enzymes may cooperate during placenta formation and functioning, possibly through a proteinase cascade. A similar colocalization of these two proteinases has already been reported in breast carcinomas (Wolf et al., 1993), as well as during mouse embryo implantation (Lefebvre et al., 1995). Recently, Pei, Majmudar and Weiss (1994) demonstrated that purified human ST3 is able to cleave $\alpha_{2}$-macroglobulin, an inhibitor of all proteinases, as well as two serine proteinase inhibitors: $\alpha_{1}$-proteinase inhibitor and the $\alpha_{2}$-antiplasmin. This demonstration reinforces the hypothesis that ST3 and $\mathrm{u}-\mathrm{PA}$ could be involved in a proteolytic cascade. Indeed, cell-bound $\mathrm{u}-\mathrm{PA}$ is a key enzyme in the initiation of the plasminogen activation cascade, a major pathway of extracellular proteolysis. Also, u-PA can convert the widely occurring zymogen plasminogen into enzymatically active plasmin (Dano et al., 1985; Liotta, Steeg and Stetler-Stevenson, 1991; Pöllänen, Stephens and Vaheri, 1991), which can directly degrade various ECM glycoproteins (Montgomery et al., 1993) and activate other matrix-degrading enzymes, such as prointerstitial collagenase (He et al., 1989; Murphy et al., 1994), pro-gelatinase B and pro-stromelysin-1 (Murphy et al., 1994) which mediate this matrix degradation. As ST3 is able to cleave and inactivate the proteinase inhibitors cited above, the concomitant production of ST3 and plasmin (via u-PA activity) by trophoblastic cells could be seen as a prerequisite for initiating a potent proteolytic cascade that enables the degradation of most ECM components. However, the capacity of other MMP to cleave plasmin inhibitors (Zhang et al., 1994; Noël et al., 1995) suggests that ST3 might also have another proteolytic activity against a more specific substrate, presently unknown (Noël et al., 1995). Our results also demonstrate that, in contrast to epithelial tumor cells which induce the synthesis of ST3 in adjacent fibroblasts (Basset, Wolf and Chambon, 1993), the invasive trophoblasts themselves produce ST3 and other proteinases which are involved in the infiltration of the maternal decidua.

From these different observations, we can conclude that ST3 expression is spatially restricted to differentiated, nonproliferative, villous (STB) and extravillous (IT, PBGC and IVT) trophoblastic populations, both of which are involved in important steps of placentation. This demonstration constitutes the first non-fibroblastic localization to be reported for ST3. All previous studies in human tissues indicated that ST3 was exclusively expressed by stromal cells (for review, see Basset, Wolf and Chambon, 1993).

\section{ACKNOWLEDGEMENTS}

We gratefully thank Professors P. Chambon and P. Basset for the generous gifts of the ST3 CDNA probe and $5 S T-4 A 9$, and I. Volders lor technical assistance in Northern blot analysis. EM is the beneficiary of grant from the Belgian National Fund for Scientific Restarch-Televic Foundation (no.7.4567.95). This work was supported by grants from the 'Communaute Française de Belgique' (Actions de Recherche Concertées 9.3/98-171 and 95/00-191), a grant (rom the Commission of European Communities (Concerted European Action, BIOMED 1 no. PL9313+6), a grant from the FNRS-I.OTTO (no.9.4561.94), a grant from the 'CGER-Assurances' and 'asbl VIVA' 1993/1996, grants from the 'Fonds de la Recherche Scientificjuc Mledicale' (no. 3.4573.95), 'Fonds National de la Recherche Scientifique-Fondation Televie' (no.7.4535.93), the 'Association contre le Cancer', the 'Association Sportive contre le Cancer', all in Belgium and a grant from the Industry (Bochringer Mannheim GmbH, Germany̧).

\section{REFERENCES}

Aplin, J. D. (1991) Implantation, trophoblast differentiation and haemochorial placentation: mechanism evidence in vivo and in vitro. Journal of $\mathrm{Ci}_{2} / \mathrm{l}$ Silence, 99, 681-692.

Autio-Harmeinen, H., Hurkainen, T., Niskasaari, K., Höyhtya, M. \& Tryggvason, K. (1992) Simultaneous expression of 70 kilodalton type IV collagenase and type IV collagen alpha I (IV) chain genes by cells of early human placenta and gestational endometrium. Laboratory Incestigation, 67, $191-200$.
Basset, P., Wolf, C. \& Chambon, P. (1993) Lxpression of the stromelysin-3 gene in fibroblastic cells of invasive carcinomas of the breast and other human tissues: a review. Breusl Cancer Research and Treatme'm, 24, 185-193.

Basset, P., Bellocq, J. P., Wolf, C., Stoll, I., Hutin, P., Limacher, J. M., Podhajcer, O. L., Chenard, M. P., Rio, M. C. \& Chambon, P. (1990) A novel metalloproteinase gene specitically expressed in stromal cells of breast carcinomas. Nature, 348, 699-704.

Behrendtsen, O., Alexander, C. M. \& Werb, Z. (1992) Metalloproteinases mediate extracellular matrix degradation by cells from mouse blastocyst outgrowths. Detelopme'm, 94, 555-560. 
Birkedal-Hansen, H., Moore, W. G., Bodden, M. K., Windsor, L. K., Birkedal-Hansen, B., DeCarlo, A. \& Engler, J. A. (1993) Matrix metalloproteinases: a review. Critical Reviems in Oral Binlogy and Medicine', $4,197-250$.

Bischof, P. \& Martelli, M. (1992) Proteolysis in the penetration phase of the implantation process. Placenta, 13, 17-24.

Bischof, P., Friedli, E., Martelli, M. \& Campana, A. (1991) Expression of extracellular matrix-degrading metalloproteinases by cultured human cytotrophoblast cells: effects of cell adhesion and immunopurification. Imerican Journal of Obstetric and G)'necology, 165, 1791-1801.

Blankenship, T. N. \& King, B. F. (199t) Identification of 72-kilodalton type IV collagenase at sites of trophoblastic invasion of macaque spiral arteries. Placenta, 15, 177-187.

Boyd, J. O. \& Hamilton, W. J. (1967) Development and structure of the human placenta from the end of the 3rd month of gestation. Journal of Obstetrics and Gynaecology, of the British Commonmealth, 74, 161-226.

Brenner, C. A., Adler, R. R., Rappolee, D. A., Pedersen, R. A. \& Werb, Z. (1989) Genes for extracellular matrix-degrading metalloproteinases and their inhibitor, TIMP, are expressed during early mammalian development. Genes and Deielopment, 3, 848-859.

Brosens, I., Robertson, W. B. \& Dixon, H. G. (1967) The physiological response of the vessels of the placental bed to normal pregnancy. Journal of Pathological Bacteriology, 93, 569-579.

Damsky, C. H., Sutherland, A. \& Fisher. S. J. (1993) Extracellular matrix 5: adhesive interactions in early mammalian embryogenesis, implantation, and placentation. F.ASEB, 7, 1320-1329.

Damsky, C. H., Fitzgerald, M. L. \& Fisher, S. J. (1992) Distribution patterns of extracellular matrix components and adhesion receptors are intricately modulated during first trimester cytotrophoblast differentiation along the invasive pathway, in vivo. Journal of Climical Investigation, 89, 210-222.

Danö, K., Andreasen, P. A., Grondahl-Hansen, J., Kristensen, P., Nielsen, L. S. \& Skriver, L. (1985) Plasminogen activators, tissue degradation, and cancer. Advances in Cancer Research, H, 139-146.

Denker, H.-W. (1993) Implantation: a cell biological paradox. Fournal of Experimental Zoolog)', 266, 541-558.

Emonard, H., Aghayan, M., Smet, M., Schaaps, J. P., Grimaud, J. A., Christiane, Y. \& Foidart J. M. (1993) Role of extracellular matrix in regulation of type IV collagenase synthesis by human trophoblast cells and their malignant counterparts. Trophoblast Research, 7, 201-210.

Emonard, H., Christiane, Y., Munaut, C. \&, Foidart, J. M. (1990) Reconstituted basement membrane matrix stimulates interstitial procollagenase synthesis by human fibroblasts in culture. Matrix, 10, 373-377.

Feinberg, R. F., Kao, L. C., Haimowitz, J. E., Queenan, J. T., Wun, T. C., Strauss III, J. F. \& Kliman, H. J. (1989) Plasminogen activator inhibitor type 1 and 2 in human trophoblasts. Laboratory Investigation, 61, $20-26$.

Fernandez, P. L., Merino, M. J., Nogales, F. F., Charonis, A. S., Stetler-Stevenson, W. \& Liotta, L. (1992) Immunohistochemical profile of basement membrane proteins and 72 kilodalton type IV collagenase in the implantation placental site. Laburatory Incestigation, 66, 572-579.

Fisher, S. J., Leitch, M. S., Kantor, M. S., Basbau, C. B. \& Kramer, R. H. (1985) Degradation of extracellular matrix by the trophoblastic cells of tirst trimester human placentas. Journal of Cellular Biochemistry, 27, $31-+1$.

Foidart, J.-M., Hustin, J., Dubois, M. \& Schaaps, J.-P. (1992) The human placenta becomes hemochorial at the 13 th week of pregnancy. Imcrnatinnal Journal of Detelopmental Biolog), 36, $451-533$.

Foidart, J.-M., Christiane, Y. \& Emonard, H. (1990) Inreractions between the human trophoblast cells and the extracellular matrix of the endometrium. Specitic expression of a-galactose residues by invasive human trophoblastic cells. Truphoblast Research, 4, 201-210.

Graham, C. H. \& Lala, P. K. (1992) Mechanisms of placental invasion of the uterus and their control. Biochemistry and Cell Biology), 70, 867-874

Hähnel, E., Harvey, J. M., Joyce, R., Robbins, P. D., Sterrett, G. F. \& Hähnel, R. (1993) Stromelysin-3 expression in breast cancer biopsies: clinico-pathological correlations. International fournal of Cancer, 55, 771774.

He, C., Wilhelm, S. M., Pentland, A. P., Marmer, B. L., Grant, G. A., Eisen, A. Z. \& Goldberg, G. I. (1989) Tissue cooperation in a proteolytic cascade activating human interstitial collagenase. Procicedings of Nadional Acudemy of Sciences of the USA, 86, 26.32-2636.

Hofmann, G. E., Glatstein, I., Schatz, F., Heller, D. \& Deligdish, L. (1994) Immunohistochemical localization of urokinase-type plasminogen activator and plasminogen activator inhibitors 1 and 2 in early human implantation sites. American fournal of Obsterics and Gynecology, 170, 671-676.

Hustin, J. \& Franchimont, J. P. (1992) The endometrium and implantation. In The First Tontece Weeks of Gestation (Ed.) Barnea, E. R., Hustin, J. \& Jauniaux, E. pp. 26-42. Berlin: Springer-Verlag.

Kawami, H., Yoshida, K., Ohsaki, A., Kuroi, K., Nishiyama, M. \& Toge, T. (1993) Stromelysin-3 mRNA expression and malignancy: comparison with clinicopathological features and type IV collagenase mRNA expression in breast tumors. Anticancer Research, 13, 2319-2324.

Kliman, H. J. \& Feinberg, R. F. (1992) Differentiation of the trophoblast. In The First Twetee Wecks of Gestation (Ed.) Barnea, E. R., Hustin, J. \& Jauniaux, E. pp. 3-25. Berlin: Springer-Verlag.

Lala, P. K. \& Graham C. H. (1990) Mechanisms of trophoblast invasiveness and their control: the role of proteases and protease inhibitors. Cancer and Metastasis Roviem, 9, 369-379.

Lefebvre, O., Wolf, C., Limacher, J. M., Hutin, P., Wendling, C., LeMeur, M., Basset, P. \& Rio, M. C. (1992) The breast cancer-associated stromelysin-3 gene is expressed during mouse mammary gland apoptosis. Journal of Cell Biology, 119, 997-1002.

Lefebvre, O., Regnier, C., Chenard, M.-P., Wendling, C., Chambon, P., Basset, P. \& Rio, M. C. (1995) Developmental expression of mouse stromelysin-3 mRNA. Development, 121, 947-955.

Librach, C. L., Werb, Z., Fitzgerald, M. L., Chiu, K., Corwin, N. M., Esteves, R., Grobelny, D., Galardy, R., Damsky, C. H. \& Fisher, S. J. (1991) 92-kD type IV collagenasc mediates invasion of human cytotrophoblasts. Journal of $\mathrm{Ce} / /$ Biology, 113, $+37-4+9$.

Liotta, L. A. (1986) Tumor invasion and metastases-role of the extracellular matrix : Rhoads Memorial Award Lecture. Cancer Research, 46, 1-7.

Liotta, L. A., Steeg, P. S. \& Stetler-Stevenson, W. G. (1991) Cancer metastasis and angiogenesis: an imbalance of positive and negative regulation. Cell, 64, 327-332.

Loke, Y. W. (1990) Experimenting with human extravillous trophoblast: a personal view. American Journal of Reproductive Immunolog)', 24, 21-28.

Moll, U. M. \& Lane, B. L. (1990) Proteolytic activity of first trimester human placenta: localization of interstitial collagenase in villous and extravillous trophoblast. Histochemistry, 94, 555-560.

Montgomery, A. M., De Clerck, Y. A., Langley, K. E., Reisfeld, R. A. \& Mueller, B. M. (1993) Mclanoma-mediated dissolution of extracellular matrix: contribution of urokinase-dependent and metalloproteinasedependent proteolytic pathways. Cancer Research, 53, 693-700.

Muller, D., Wolf, C., Abecassis, J., Millon, R., Engelmann, A., Bronner, G., Rouyer, N., Rio, M. C., Eber, M., Methlin, G., Chambon, P. \& Basset, P. (1993) Increased stromelysin 3 gene expression is associated with increased local invasiveness in head and neck squamous cell carcinomas. Cancer Research, 53, 165-169

Murphy, G., Segain, J.-P., O'Shea, M., Cockett, M., Ioannou, C., Lefebvre, O., Chambon, P. \& Basset, P. (1993) The 28-kDa N-terminal domain of mouse stromelysin-3 has the general properties of a weak metalloprotcinase. Fournal of Biological Chemistry, 268, 15+35-15441.

Murphy, G., Willenbrock, F., Crabbe, T., O'Shea, M., Ward, R., Atkinson, S., O'Connell, J. \& Docherty, A. (1994) Regulation of matrix metalloproteinase activity. Amals of the' $N^{\prime}$ m York .tiademy of Sciences, 732, $31-+1$.

Nawrocki, B., Polette, M., Marchand, V., Maquoi, E., Tournier, J. M., Foidart, J.-M. \& Birembaut, P. (1996) Membrane-type matrix metalloproteinase-1 expression at the site of human placentation. Placenta, $17,565-572$.

Noël, A., Santavicca, M., Stoll, I., L'Hoir, C., Staub, A., Murphy, G., Rio, M. C. \& Basset, P. (1995) Identification of structural determinants controlling human and mouse stromclysin-3 proteolytic activities. Journal of Biological Chemistry, 270, 22866-22872.

Patterson, D., Pär Hayes, W. \& Shi, Y.-B. (1995) Transcriptional activation of the matrix metalloprotcinase gene stromelysin-3 coincides with thyroid hormone-induced cell death during frog metamorphosis. Developmental Biology, 167, 252-262.

Pei, D., Majmudar, G. \& Weiss, S. J. (1994) Hydrolytic inactivation of a breast carcinoma cell-derived serpin by human stromelysin-3. Journal of Binlogical Chemisiry, 269, 25849-25855.

Pijnenborg, R., Dixon, G., Robertson, W. B. \& Brosens, I. (1980) Trophoblastic invasion of human decidua from 8 to 18 weeks of pregnancy. Plucenta, 1, 3-19.

Polette, M., Clavel, C. Birembaut, P. \& De Clerck, Y. A. (1993) Localization by in situ hybridization of mRNAs encoding stromelysin 3 and 
tissue inhibitors of metallo-proteinases TIMP-1 and TIMP-2 in human head and neck carcinomas. Palhology Research and Practice, 189, 1052-1057.

Polette, M., Nawrocki, B., Pintiaux, A., Massenat, C., Maquoi, E., Volders, L., Schaaps, J. P., Birembaut, P. \& Foidart, J. M. (1994) Expression of relatinases $A$ and $B$ and their tissue inhibitors by cells of early and term human placenta and gestational endometrium. Laboratory' Incestigation, 71, 838-846.

Pöllänen, J., Stephens, R. W. \& Vaheri, A. (1991) Plasminogen activation at the surface of normal and malignant cells. Adzances in Cancer Research, 57 , 273-280.

Santavicea, M., Noël, A., Lutz, Y., Stoll, I., Segain, J.-P., Rouyer, N. \& Basset, P. (1995) Characterization of monoclonal antibodics against stromelysin-3 and their use to evaluate stromelysin-3 levels in human breast carcinomas. Internatimal fourmal of Cancer, 64, 3.36-341.

Santavicca, M., Noël, A., Angliker, H., Stoll, I., Segain, J.-P. \& Anglard, P. (1996) Characterization of structural determinants and molecular mechanisms involved in pro-stromelysin-3 activation by t-aminophenylmercuric acetate and furin-type convertases. Biochemical fournal, 315, 953-958.

Sappino, A. P., Huarte, J., Belin, D. \& Vassali, J. D. (1989) Plasminogen acrivator in tissue remodeling and invasion: mRNA localization in mouse ovaries and implanting embryos. Fournal of Cell Biolog)', 109, 2471-2479.

Seftor, R. E., Seftor, E. A., Stetler-Stevenson, W. G. \& Hendrix, M. J. (1993) The $72 \mathrm{kDa}$ type IV collagenase is modulated via differential expression of $\alpha \cdot \beta 3$ and $\alpha 5 \beta 1$ integrins during human melanoma cell invasion. Cancer Research, 53, 3411-3+15.

Seltzer, J. L., Lec, A. Y., Akers, K. 'T., Sudbeck, B., Southon, E. A., Wayner, E. A. \& Eisen, A. Z. (1994) Activation of $72-\mathrm{kDa}$ type IV collagenase/gelatinase by normal fibroblasts in collagen lattices is mediated by integrin receptors but is not related to lattice contraction. Experimen/al Cell Resturch, 213, 365-374.

Sherman, M. I., Strickland, S. \& Reich, E. (1976) Differentiation in carly mouse embryonic and teratocarcinoma cells in vitro: plasminogen activator production. Cancer Reserarch, 36, +208-4216.

Strickland, S., Reich, E. \& Sherman, M. I. (1976) Plasminogen activator in early embryogenesis: enzyme production by trophoblast and parietal endoderm. $C \cdot l l, 9,231-240$.

Strickland, S. \& Richards, W. G. (1992) Invasion of the trophoblasts. Ce'l, $71,355-357$.
Tuttel, S. E., O'Toole, R. V., O'Shaughnessy, R. W. \& Zuspan, F. P. (1985) Immunochemical evaluation of human placental implantation: an initial study. American fournal of Obstetrics and Gyecology, 153, 239-244.

Urbanski, S. J., Edwards, D. R., Maitland, A., Leco, K. J., Watson, A. \& Kossakowska, A. E. (1992) Expression of metalloproteinases and their inhibitors in primary pulmonary carcinomas. British Journal of Canccr, 66, 1188-1194.

Werb, Z., Mainardi, C. L., Vater, C. A. \& Harris, E. D. (1977) Endogenous activation of latent collagenases by rheumatoid synovial cells. Evidence for a role of plasminogen activator. New England fournal of Medicine, 296, 1017-1022.

Werb, Z., Tremble, P. M., Behrendtsen, O., Crowley, E. \& Damsky, C. H. (1989) Signal transduction through the fibronectin receptor induces collagenase and stromelysin gene expression. Journal of Cell Biolog)', 109 , $877-889$.

Wewer, U. M., Faber, M., Liotta, L. \& Albrechtsen, R. (1985) Immunochemical and ultrastructural assessment of the nature of the pericellular basement membrane of human decidual cells. Laboratory' Inzestigalion, 53, $62+63.3$.

Wolf, C., Chenard, M.-P., Durand de Grossouvre, P., Bellocq, J.-P., Chambon, P. \& Basset, P. (1992) Breast-cancer-associated stromelysin-3 gene is expressed in basal cell carcinoma and during cutancous wound healing. Journal of Inecstigatize Dermatolog), 99, 870-872.

Wolf, C., Rouyer, N., Lutz, Y., Adida, C., Loriot, M., Bellocq, J.-P. Chambon, P. \& Basset, P. (1993) Stromelysin-3 belongs to a subgroup of proteinases expressed in breast carcinoma fibroblastic cells and possibly implicated in tumor progression. Procedings of the National Atadem. of Scionces of the US.4, 90, 1843-1847.

Yagel, S., Parhar, R. S., Jeffrey, J. J. \& Lala, P. K. (1988) Normal non-metastatic trophoblast cells share in vitro invasive properties of malignant cells. Journal of $C_{c} / l$ Physiologk, 136, 455-464.

Zhang, Z., Winyard, P. G., Chidwick, K., Murphy, G., Wardell, M., Carrell, R. W. \& Blake, D. R. (1994) Proteolysis of human native and oxidised alpha 1-proteinase inhibitor by matrilysin and stromelysin. Biochemica et Biophysica Arla, 1199, 22+-228.

Zini, J.-M., Murray, S. C., Graham, C. H., Lala, P. K., Karikò, K. \& Barnathan, E. S. (1992) Characterization of urokinase receptor expression by human placental trophoblasts. B/ood, 79, 2917-2929. 